Vol. 8, No. 2, 2021, pp. 87-99

\title{
ANALISIS PERBANDINGAN KINERJA KEUANGAN BUS DAN UUS ANTARA SEBELUM DAN SELAMA PANDEMI COVID-19
}

\author{
Asmirawati \\ Universitas Islam Indonesia \\ Email: khaulah.asmiraa@gmail.com \\ Mia Kurniati \\ Universitas Islam Indonesia \\ Email: miakurniati66@gmail.com
}

\begin{abstract}
This study aims to analyze the financial performance of Islamic commercial banks and Islamic business units between before and during the pandemic. This study uses an analysis of the soundness of banks known as CAMEL, which is proxied into the ratio of CAR, NPF, ROA, BOPO and FDR. This study uses a quantitative method by using a comparative approach that compares the similarities or differences of two or more properties and objects studied in a certain frame of mind. This study uses monthly financial reports in 2019-2020. The population of this research is Islamic commercial banks and Islamic business units that issue monthly financial reports. The statistical method used is the descriptive statistical test and Wilcoxon signed-rank test. The results show significant differences in the CAR ratio of Islamic commercial banks, NPF of Islamic commercial banks and Islamic business units, BOPO of Islamic business units, and FDR of Islamic commercial banks. Meanwhile, there was no significant difference between before and during the pandemic for the ROA of Islamic commercial banks and Islamic business units, BOPO of Islamic commercial banks, and FDR of Islamic business units.
\end{abstract}

Keywords: Islamic commercial banks, CAMEL, financial performance, Covid19, financial soundness

\section{PENDAHULUAN}

Pandemi Corona Virus Desease (Covid-19) telah menjadi isu kesehatan global. Covid19 pertama kali dilaporkan pada 31 Desember 2019 di Wuhan, Cina. Covid-19 terus menyebar ke seluruh negara termasuk Indonesia karena penyebarannya yang sangat cepat. Penyebaran Covid-19 telah dinyatakan sebagai pandemi oleh World Health Organization. Di Indonesia, kasus pertama diumumkan secara resmi oleh Presiden pada tanggal 2 Maret 2020. Sejak resmi diumumkan di Indonesia, jumlah kasus positif semakin bertambah dengan cepat, sehingga lahir berbagai kebijakan yang dikeluarkan oleh pemerintah, seperti kebijakan work from home (WFH), physical distancing yang menghimbau masyarakat untuk tetap di rumah, memakai masker, penggunaan hand sanitizer dan penyemprotan disinfektan, pelarangan mudik lebaran tahun 2020 dan 2021, dan pembatasan sosial berskala besar (PSBB). Covid-19 telah memberikan dampak ke seluruh aspek kehidupan, sosial, politik dan ekonomi, termasuk perbankan. Dalam konteks perbankan, Covid-19 berimbas terhadap perlambatan pertumbuhan pembiayaan, meningkatnya pembiayaan bermasalah yang disebabkan oleh banyaknya masyarakat yang kehilangan mata pencahariannya. Selain itu, Ketua Dewan Komisioner Otoritas Jasa Keuangan (OJK), Wimboh Santoso, mengatakan bahwa kinerja intermediasi industri perbankan di 2020 mengalami tekanan. Penyaluran kredit bank minus 2,41\% karena perlambatan sektor riil yang diakibatkan oleh masih banyak perusahaan korporasi yang belum berjalan dengan penuh (Al Faqir, 2021). 
Asmirawati, Mia Kurniati | Analisis Perbandingan Kinerja Keuangan BUS dan UUS Antara Sebelum dan Selama Pandemi Covid-19

Sementara itu, risiko pembiayaan bermasalah juga semakin meningkat. OJK memperkirakan bahwa risiko pembiayaan bermasalah (Non-Performing Loan/NPL) akan terus mengalami peningkatan. NPL meningkat dari 2,53\% pada akhir 2019 menjadi 3,06 \% pada Desember 2020 (CNN Indonesia, 2021). Sementara itu, Menteri Keuangan, Sri Mulyani Indrawati, mengatakan bahwa keuangan syariah mampu bertahan di tengah guncangan krisis Covid-19. Hal ini terlihat dari rasio kecukupan modal (CAR) yang masih stabil pada angka $20-21 \%$ dan rasio pembiayaan bermasalah (NPF) yang mengalami penurunan dari 3,46\% pada Januari 2020 menjadi 3,13\% pada Desember 2020. Salah satu indikator yang biasa digunakan dalam mengukur kinerja keuangan bank adalah dengan cara melakukan penilaian tingkat kesehatan bank yang dikenal dengan Metode CAMEL (Capital, Asset, Management, Earning, dan Liquidity). Metode ini melakukan penilaian tingkat kesehatan bank dengan cara menghitung besarnya rasio CAR (rasio permodalan), NPL (mewakili rasio kualitas aktiva produktif), ROA dan ROE (mewakili rasio rentabilitas), BOPO (mewakili rasio efisiensi), dan LDR (mewakili rasio likuiditas).

Penelitian terkait kinerja keuangan dan rasio keuangan cukup banyak diteliti. Studi yang dilakukan oleh Rashid dkk. (2017) terkait pengaruh bank Islam atau bank syariah terhadap stabilitas keuangan khususnya stabilitas perbankan yang beroperasi di Pakistan menyatakan bahwa rasio profitabilitas, rasio pinjaman terhadap aset, ukuran bank memiliki pengaruh terhadap stabilitas bank. Sementara penelitian yang dilakukan oleh Ledhem dan Mekidiche (2020) yang menggunakan pendekatan CAMELS menunjukkan bahwa ROE berpengaruh positif dan signifikan terhadap pertumbuhan ekonomi. Sementara Setyawati dkk. (2017) yang menganalisis faktor internal dan eksternal yang mempengaruhi kinerja keuangan perbankan syariah di Indonesia serta pengaruh krisis global terhadap kinerja keuangan bank syariah menunjukkan bahwa variabel non-performing financing berpengaruh signifikan terhadap kinerja keuangan bank syariah.

Putri dan Iradianty (2020) menggunakan enam rasio keuangan dalam penelitiannya, yaitu capital adequacy ratio, non-performing financing, return on equity, beban operasional dibagi pendapatan operasional, financing to deposit ratio, dan debt to equity ratio. Penelitian tersebut menggunakan data sekunder yang diperoleh dari laporan keuangan tahunan dari setiap perusahaan perbankan syariah dan perbankan konvensional yang terdaftar di Bursa Efek Indonesia periode 2015-2016. Sementara Thayib dkk. (2017) membuat model penelitian atau kerangka konseptual dengan menggunakan enam rasio keuangan yaitu, non performing loan, loan to debt ratio, capital adequacy ratio, debt to equity ratio, return on asset, dan return on equity. Rasio yang digunakan oleh Putri dan Iradianty (2020) sudah lengkap karena sudah mewakili analisis-analisis rasio yang diperlukan untuk menilai kinerja keuangan perbankan, sedangkan penelitian yang dilakukan oleh Thayib dkk. (2017) belum mencerminkan rasio efisiensi operasional.

Penelitian terkait perbandingan antara kinerja keuangan perbankan konvensional dan perbankan syariah sudah sangat banyak diteliti, akan tetapi belum ada penelitian yang membandingkan kinerja Bank Umum Syariah (BUS) dan Unit Usaha Syariah (UUS) sebelum dan selama pandemi Covid-19. Penelitian yang membandingkan kinerja bank konvensional dan bank syariah antara sebelum dan selama pandemi Covid-19 seperti yang dilakukan oleh Surya dan Asiyah (2020) masih sangat terbatas. Penelitian tersebut hanya meneliti pada satu sektor perbankan yaitu perbankan syariah dengan subjek penelitian yang hanya terdiri atas dua bank, yaitu BNI syariah dan Bank Mandiri Syariah. Penelitian lain terkait kinerja keuangan di masa pandemi juga telah dilakukan oleh Fitriani (2020) dan Ichsan dkk. (2021), akan tetapi penelitian tersebut hanya dilakukan pada masa pandemi Covid-19 yang mengambil perbankan syariah sebagai subjek penelitian. Penelitian yang menjelaskan secara eksplisit terkait perbandingan kinerja keuangan BUS dan UUS antara sebelum dan selama pandemi Covid-19 belum pernah dilakukan. Oleh karena itu, penelitian terkait kinerja keuangan BUS dan UUS sebelum dan selama pandemi Covid-19 penting untuk dikaji dan diteliti lebih mendalam. Berdasarkan uraian latar belakang masalah tersebut, penelitian ini bertujuan untuk 
Asmirawati, Mia Kurniati | Analisis Perbandingan Kinerja Keuangan BUS dan UUS Antara Sebelum dan Selama Pandemi Covid-19

membandingkan kinerja keuangan bank syariah yang terdiri atas Bank Umum Syariah dan Unit usaha syariah antara sebelum dan selama pandemi Covid-19 ditinjau dari segi rasio keuangan dengan menggunakan indikator tingkat kesehatan keuangan atau yang dikenal dengan istilah CAMEL.

\section{TINJAUAN PUSTAKA}

\section{Bank Syariah}

Bank syariah adalah bank yang dibangun sesuai dengan prinsip syariah (Budisantoso \& Nuritomo, 2014), yang berarti bahwa segala aktivitas bisnisnya mengikuti ajaran agama Islam yaitu sesuai Al-Quran dan sunnah. Menurut Surya dan Asiyah (2020) bank syariah yaitu bank yang aktivitas operasionalnya meliputi penyaluran maupun penghimpunan dana dengan memberikan imbalan berdasarkan prinsip syariah, yakni bagi hasil serta jual beli. Sejalan dengan itu, Sudarsono (2012) menyatakan bahwa bank syariah adalah lembaga keuangan yang usaha pokoknya memberikan pembiayaan dan jasa-jasa lain dalam lalu lintas pembayaran serta peredaran uang yang beroperasi dengan prinsip-prinsip syariat Islam.

\section{Bank Umum Syariah}

Bank Umum Syariah (BUS) merupakan bank yang memberikan kegiatan usaha jasa lalu lintas pembayaran dan dalam pelaksanaannya menggunakan prinsip syariah. Menurut Undang-Undang Nomor 21 Tahun 2008 tentang Perbankan Syariah, ketika ingin memperoleh izin usaha maka BUS harus memenuhi persyaratan, yaitu susunan organisasi dan kepengurusan, permodalan, kepemilikan, keahlian di bidang perbankan syariah, dan kelayakan usaha. Selain itu, Undang-Undang Nomor 21 Tahun 2008 tentang Perbankan Syariah pada Pasal 24 memuat larangan-larangan bagi bank umum syariah, yaitu melaksanakan kegiatan usaha yang tidak sesuai dengan prinsip syariah, melakukan jual beli saham secara langsung di pasar modal, melakukan penyertaan modal, serta melakukan kegiatan usaha yang berkaitan dengan perasuransian, kecuali bertindak sebagai agen pemasaran produk asuransi syariah.

\section{Unit Usaha Syariah}

Unit Usaha Syariah (UUS) merupakan unit kerja dari kantor pusat bank umum konvensional yang memiliki fungsi sebagai kantor induk dari kantor atau unit yang melaksanakan kegiatan usaha yang berbasis atau berprinsip syariah, atau kegiatan usaha secara konvensional yang memiliki fungsi sebagai sebagai kantor induk dari kantor cabang pembantu syariah dan/atau unit syariah. UUS juga dapat berusaha sebagai bank devisa atau non devisa. UUS sebagai suatu unit kerja khusus memiliki tugas, yaitu mengatur serta mengawasi seluruh kegiatan kantor cabang syariah, melakukan fungsi treasury dalam rangka pengelolaan dan penempatan dana yang bersumber dari kantor cabang syariah, membuat laporan keuangan konsolidasi dari semua kantor cabang syariah, dan melaksanakan tugas penatausahaan laporan keuangan kantor cabang syariah. Undang-Undang Nomor 21 Tahun 2008 tentang Perbankan Syariah pada Pasal 24 juga menjelaskan terkait larangan-larangan UUS, yaitu menjalankan kegiatan usaha yang tidak sesuai atau bertentangan dengan prinsip syariah, melaksanakan kegiatan jual beli saham di pasar modal secara langsung, melakukan penyertaan modal, serta melaksanakan kegiatan usaha perasuransian, kecuali sebagai agen pemasaran produk asuransi syariah.

\section{Kinerja Keuangan}

Kinerja (performance) dalam kamus istilah akuntansi adalah kuantifikasi dari keefektifan dalam pengoperasian bisnis selama periode tertentu (Joel \& Shim, 1994). Kinerja keuangan adalah gambaran hasil ekonomi yang mampu diraih oleh perusahaan atau perbankan pada periode tertentu melalui aktivitas-aktivitas perusahaan untuk menghasilkan keuntungan secara efisien dan efektif yang dapat diukur perkembangannya dengan menganalisis data-data keuangan yang tercantum dalam 
Asmirawati, Mia Kurniati | Analisis Perbandingan Kinerja Keuangan BUS dan UUS Antara Sebelum dan Selama Pandemi Covid-19

laporan keuangan (Putri \& Dharma, 2016). Kinerja perbankan secara umum merupakan gambaran prestasi yang dicapai oleh bank dalam operasionalnya, sedangkan kinerja keuangan perbankan merupakan gambaran kondisi keuangan bank pada suatu periode tertentu baik menyangkut aspek penghimpunan dana maupun penyaluran dana (Munir, 2017). Menurut Golovkova dkk. (2019), kinerja keuangan tidak dibatasi oleh pengukuran yang sifatnya kuantitatif semata, akan tetapi dipengaruhi juga oleh hubungan dengan nasabah dan kualitas hubungan dengan institusi keuangan lainnya. Penelitian ini juga didukung oleh studi yang dilakukan oleh Fusva dkk., (2020). Metode CAMEL adalah cara penilaian tingkat kesehatan bank yang dilakukan dengan menghitung besarnya lima rasio keuangan, yaitu CAR mewakili rasio permodalan, NPF mewakili rasio kualitas aktiva produktif, ROA mewakili rasio rentabilitas, BOPO mewakili rasio efisiensi, dan FDR mewakili rasio likuiditas.

\section{Rerangka Penelitian}

Terdapat lima rasio keuangan yang digunakan dalam penelitian ini, yaitu CAR, NPF, ROA, BOPO, dan FDR. Pengujian hipotesis dalam penelitian ini menggunakan paired sample t-test jika data berdistribusi normal, dan Wilcoxon signed-rank test jika data tidak berdistribusi normal. Gambar 1 menunjukkan rerangka pemikiran yang digunakan dalam penelitian ini.

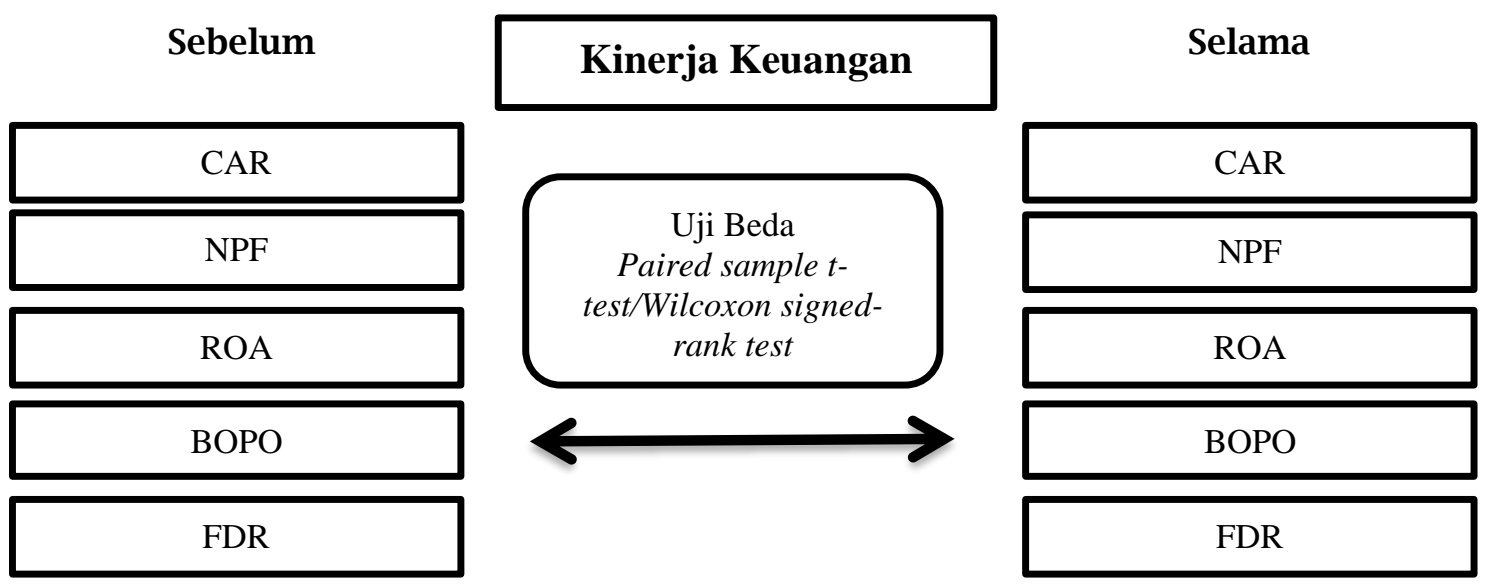

Gambar 1. Rerangka Pemikiran

Berdasarkan rerangka pemikiran pada Gambar 1, maka hipotesis dalam penelitian ini dirumuskan sebagai berikut.

H1: Terdapat perbedaan kinerja keuangan BUS yang diukur dengan rasio CAR pada saat sebelum pandemi Covid-19 dan selama pandemi Covid-19.

H2: Terdapat perbedaan kinerja keuangan BUS yang diukur dengan rasio NPF pada saat sebelum pandemi Covid-19 dan selama pandemi Covid-19.

H3: Terdapat perbedaan kinerja keuangan UUS yang diukur dengan rasio NPF pada saat sebelum pandemi Covid-19 dan selama pandemi Covid-19.

H4: Terdapat perbedaan kinerja keuangan BUS yang diukur dengan rasio ROA pada saat sebelum pandemi Covid-19 dan selama pandemi Covid-19.

H5: Terdapat perbedaan kinerja keuangan UUS yang diukur dengan rasio ROA pada saat sebelum pandemi Covid-19 dan selama pandemi Covid-19.

H6: Terdapat perbedaan kinerja keuangan BUS yang diukur dengan rasio BOPO pada saat sebelum pandemi Covid-19 dan selama pandemi Covid-19.

H7: Terdapat perbedaan kinerja keuangan UUS yang diukur dengan rasio BOPO pada saat sebelum pandemi Covid-19 dan selama pandemi Covid-19. 
Asmirawati, Mia Kurniati | Analisis Perbandingan Kinerja Keuangan BUS dan UUS Antara Sebelum dan Selama Pandemi Covid-19

H8: Terdapat perbedaan kinerja keuangan BUS yang diukur dengan rasio FDR pada saat sebelum pandemi Covid-19 dan selama pandemi Covid-19.

H9: Terdapat perbedaan kinerja keuangan UUS yang diukur dengan rasio FDR pada saat sebelum pandemi Covid-19 dan selama pandemi Covid-19.

\section{METODE PENELITIAN}

Populasi dalam penelitian ini adalah BUS dan UUS yang terdaftar di Otoritas Jasa Keuangan (OJK) pada periode 2019-2020. Teknik pengambilan sampel dalam penelitian ini menggunakan metode purposive sampling. Metode pengumpulan data yang digunakan yaitu studi pustaka dan dokumentasi. Penelitian ini menggunakan rasio kesehatan keuangan yang dikenal dengan CAMEL yang diproksikan dengan rasio CAR, NPF, ROA, BOPO, dan FDR. Penelitian ini menggunakan metode kuantitatif dengan pendekatan komparatif, yaitu membandingkan persamaan dan perbedaan dua atau lebih sifat dari fakta objek yang diteliti. Metode analisis data yang digunakan, yaitu paired sample t-test jika data berdistribusi normal dan Wilcoxon signed-rank test jika data data tidak berdistribusi normal.

\section{Capital Adequacy Ratio (CAR)}

Menurut Peraturan Bank Indonesia Nomor 9/13/PBI/2007, CAR adalah penyediaan modal minimum bagi bank yang didasarkan pada risiko aktiva, baik aktiva yang tercantum dalam neraca maupun aktiva yang bersifat administratif sebagaimana tercermin pada kewajiban yang masih bersifat kontinjen dan/atau komitmen yang disediakan oleh bank bagi pihak ketiga maupun risiko pasar. Rasio CAR digunakan untuk mengukur kecukupan modal yang dimiliki bank untuk menunjang aktiva yang mengandung atau menghasilkan risiko. Semakin tinggi CAR maka semakin kuat kemampuan bank tersebut untuk menanggung risiko dan bank mampu membiayai operasional bank.

$$
C A R=\frac{\text { Modal }}{\text { ATMR }} \times 100 \%
$$

Kriteria penilaian tingkat kesehatan bank berdasarkan komponen CAR dapat dilihat pada Tabel 1.

Tabel 1. Matriks Kriteria Peringkat Komponen CAR

\begin{tabular}{ccc}
\hline Rasio & Peringkat & Predikat \\
\hline CAR $\geq 12 \%$ & 1 & Sangat Baik \\
$9 \% \leq \mathrm{CAR}<12 \%$ & 2 & Baik \\
$8 \% \leq \mathrm{CAR}<9 \%$ & 3 & Cukup \\
$6 \%<\mathrm{CAR}<8 \%$ & 4 & Tidak Baik \\
CAR $\leq 6 \%$ & 5 & Sangat Tidak Baik \\
\hline
\end{tabular}

Sumber: Kodifikasi Peraturan Bank Indonesia tentang Penilaian Tingkat Kesehatan Bank

\section{Non-Performing Financing (NPF)}

NPF merupakan rasio pembiayaan bermasalah dengan total pembiayaan. Pembiayaan bermasalah adalah pembiayaan dengan kualitas kurang lancar, diragukan dan macet. Standar yang ditetapkan oleh Bank Indonesia adalah kurang dari 5\%, sehingga Penyisihan Penghapusan Aktiva Produktif (PPAP) yang harus disediakan bank guna menutup kerugian yang ditimbulkan oleh aktiva produktif non lancar (dalam hal ini pembiayaan bermasalah) menjadi kecil (Purwoko \& Sudiyatno, 2013).

$$
N P F=\frac{\text { Pembiayaan bermasalah }}{\text { Total pembiayaan }} \times 100 \%
$$

Kriteria penilaian tingkat kesehatan bank berdasarkan komponen NPF dapat dilihat pada Tabel 2. 
Asmirawati, Mia Kurniati | Analisis Perbandingan Kinerja Keuangan BUS dan UUS Antara Sebelum dan Selama Pandemi Covid-19

Tabel 2. Matriks Kriteria Peringkat Komponen NPF

\begin{tabular}{ccc}
\hline Rasio & Peringkat & Predikat \\
\hline$\leq 7 \%$ & 1 & Sangat Baik \\
$7 \%<\mathrm{NPF} \leq 10 \%$ & 2 & Baik \\
$10 \%<\mathrm{NPF} \leq 13 \%$ & 3 & Cukup \\
$13 \%<\mathrm{NPF} \leq 16 \%$ & 4 & Tidak Baik \\
$\mathrm{NPF}>16 \%$ & 5 & Sangat Tidak Baik \\
\hline Sumber: Kodifikasi Peraturan Bank Indonesia tentang Penilaian Tingkat Kesehatan \\
\multicolumn{2}{c}{ Bank }
\end{tabular}

\section{Return on Asset (ROA)}

ROA mengukur efektivitas atau kemampuan manajemen bank dalam menghasilkan income dari pengelolaan aset yang dimiliki. ROA memberikan informasi tentang seberapa efisien sebuah bank sedang berjalan, karena menunjukkan berapa banyak keuntungan yang dihasilkan (Mishkin, 2016). Semakin besar ROA suatu bank, semakin besar pula tingkat keuntungan yang dicapai bank tersebut dan semakin baik posisi bank tersebut dari segi penggunaan aset.

$$
R O A=\frac{\text { Laba sebelum pajak }}{\text { Rata }- \text { rata total aset }} \times 100 \%
$$

Kriteria penilaian tingkat kesehatan bank berdasarkan komponen ROA dapat dilihat pada Tabel 3.

Tabel 3. Matriks Kriteria Peringkat Komponen ROA

\begin{tabular}{ccc}
\hline Rasio & Peringkat & Predikat \\
\hline ROA $>1,5 \%$ & 1 & Sangat Baik \\
$1,25 \%<\mathrm{ROA} \leq 1,5 \%$ & 2 & Baik \\
$0,5 \%<\mathrm{ROA} \leq 1,25 \%$ & 3 & Cukup \\
$0<\mathrm{ROA} \leq 0,5 \%$ & 4 & Tidak Baik \\
$\mathrm{ROA} \leq 0 \%$ & 5 & Sangat Tidak Baik \\
\hline
\end{tabular}

Sumber: Kodifikasi Peraturan Bank Indonesia tentang Penilaian Tingkat Kesehatan Bank

\section{Biaya Operasional Pendapatan Operasional (BOPO)}

BOPO merupakan rasio efisiensi yang digunakan untuk mengukur kemampuan manajemen bank dalam mengendalikan biaya operasional terhadap pendapatan operasional. Bank yang efisien dalam menekan biaya operasionalnya dapat mengurangi kerugian akibat ketidakefisienan bank dalam mengelola usahanya sehingga meningkatkan laba (Arimi \& Mahfud, 2012). Standar terbaik BOPO menurut Bank Indonesia adalah 92\%. Semakin kecil rasio ini berarti semakin efisien biaya operasional sehingga kemungkinan suatu bank dalam kondisi bermasalah semakin kecil.

$$
\text { BOPO }=\frac{\text { Total beban operasional }}{\text { Total pendapatan operasional }} \times 100 \%
$$

Kriteria penilaian tingkat kesehatan bank berdasarkan komponen BOPO dapat dilihat pada Tabel 4.

Tabel 4. Matriks Kriteria Peringkat Komponen BOPO

\begin{tabular}{ccc}
\hline Rasio & Peringkat & Predikat \\
\hline $50 \%-75 \%$ & 1 & Sangat Baik \\
$76 \%-93 \%$ & 2 & Baik \\
$94 \%-96 \%$ & 3 & Cukup \\
$96 \%-100 \%$ & 4 & Tidak Baik \\
$>100 \%$ & 5 & Sangat Tidak Baik \\
\hline
\end{tabular}

Sumber: Surat Edaran Bank Indonesia No.6/23/ DPNP tanggal 13 Mei 2014 
Asmirawati, Mia Kurniati | Analisis Perbandingan Kinerja Keuangan BUS dan UUS Antara Sebelum dan Selama Pandemi Covid-19

\section{Financing to Deposit Ratio (FDR)}

Menurut Riyadi (2015), FDR adalah perbandingan total pembiayaan terhadap dana pihak ketiga yang dihimpun oleh bank. Rasio ini menunjukkan tingkat kemampuan bank dalam hal penyaluran dana yang bersumber dari masyarakat (berupa: tabungan, sertifikat deposito berjangka, giro, deposito berjangka, dan kewajiban segera lainnya) dalam bentuk pembiayaan.

$$
F D R=\frac{\text { Total pembiayaan kepada pihak ketiga bukan bank }}{\text { Total dana pihak ketiga }} \times 100 \%
$$

Semakin tinggi nilai rasio FDR menunjukkan semakin rendahnya likuiditas bank yang bersangkutan sehingga kemungkinan bank tersebut dalam kondisi bermasalah akan semakin besar.

Kriteria penilaian berdasarkan komponen FDR dapat dilihat pada Tabel 5.

Tabel 5. Matriks Kriteria Peringkat Komponen FDR

\begin{tabular}{ccc}
\hline Rasio & Peringkat & Predikat \\
\hline FDR $\leq 75 \%$ & 1 & Sangat Baik \\
$75 \%<$ FDR $\leq 85 \%$ & 2 & Baik \\
$85 \%<$ FDR $\leq 100 \%$ & 3 & Cukup \\
$100 \%<$ FDR $<120 \%$ & 4 & Tidak Baik \\
FDR $>120 \%$ & 5 & Sangat Tidak Baik \\
\hline
\end{tabular}

Sumber: Kodifikasi Peraturan Bank Indonesia tentang Penilaian Tingkat Kesehatan Bank

\section{HASIL DAN PEMBAHASAN}

\section{Uji Normalitas}

Hasil uji normalitas kinerja keuangan Bank Umum Syariah menggunakan One-Sample Kolmogorov-Smirnov Test dijelaskan dalam Tabel 6.

Tabel 6. Hasil Uji Normalitas Kinerja Keuangan Bank Umum Syariah One-Sample Kolmogorov-Smirnov Test

\begin{tabular}{lccc}
\hline & Statistic & df & Sig. \\
\hline CAR_Sebelum & 0,240 & 12 & 0,054 \\
NPF_Sebelum & 0,175 & 12 & 0,200 \\
ROA_Sebelum & 0,198 & 12 & 0,200 \\
BOPO_Sebelum & 0,199 & 12 & 0,200 \\
FDR_Sebelum & 0,107 & 12 & 0,200 \\
\hline CAR_Selama & 0,243 & 12 & 0,049 \\
NPF_Selama & 0,142 & 12 & 0,200 \\
ROA_Selama & 0,305 & 12 & 0,003 \\
BOPO_Selama & 0,280 & 12 & 0,010 \\
FDR_Selama & 0,189 & 12 & 0,200 \\
\hline
\end{tabular}

Sumber: Data diolah SPSS 2021

Berdasarkan Tabel 6, hasil uji normalitas Kolmogorov Smirnov pada BUS menunjukkan bahwa data CAR, ROA dan BOPO selama pandemi Covid-19 tidak berdistribusi normal. Hal ini ditunjukkan dengan nilai asymp. Sig (2-tailed) masingmasing lebih kecil dari 0,05. Karena data tidak berdistribusi normal maka uji hipotesis yang digunakan adalah uji Wilcoxon signed-rank test.

Hasil uji normalitas kinerja keuangan Unit Usaha Syariah One-Sample KolmogorovSmirnov Test dijelaskan dalam Tabel 7. 
Asmirawati, Mia Kurniati | Analisis Perbandingan Kinerja Keuangan BUS dan UUS Antara Sebelum dan Selama Pandemi Covid-19

Tabel 7. Hasil Uji Normalitas Kinerja Keuangan Unit Usaha Syariah One-Sample Kolmogorov-Smirnov Test

\begin{tabular}{lccc}
\hline & Statistic & df & Sig. \\
\hline NPF_Sebelum & 0,193 & 12 & 0,200 \\
ROA_Sebelum & 0,207 & 12 & 0,164 \\
BOPO_Sebelum & 0,215 & 12 & 0,131 \\
FDR_Sebelum & 0,190 & 12 & 0,200 \\
\hline NPF_Selama & 0,274 & 12 & 0,013 \\
ROA_Selama & 0,218 & 12 & 0,120 \\
BOPO_Selama & 0,194 & 12 & 0,200 \\
FDR_Selama & 0,230 & 12 & 0,081 \\
\hline
\end{tabular}

Sumber: Data diolah SPSS 2021

Berdasarkan Tabel 7, hasil uji normalitas Kolmogorov-Smirnov pada UUS, data NPF selama pandemi Covid-19 tidak berdistribusi normal, hal ini ditunjukkan nilai asymp. Sig (2-tailed) masing-masing lebih kecil dari 0,05. Karena data tidak berdistribusi normal, maka uji hipotesis yang digunakan adalah uji Wilcoxon signed-ranks test.

\section{Hasil Statistik Deskriptif}

Statistik deskriptif sebelum dan selama pandemi dijelaskan dalam Tabel 8.

Tabel 8. Statistik Deskriptif Sebelum dan Selama Pandemi

\begin{tabular}{lccccc}
\hline & N & Minimum & Maximum & Mean & $\begin{array}{c}\text { Std. } \\
\text { Deviation }\end{array}$ \\
\hline CAR_SebelumBUS & 12 & 19,56 & 20,59 & 20,1233 & 0,41179 \\
NPF_SebelumBUS & 12 & 3,23 & 3,58 & 3,4183 & 0,09301 \\
ROA_SebelumBUS & 12 & 1,46 & 1,88 & 1,6542 & 0,12184 \\
BOPO_SebelumBUS & 12 & 81,95 & 86,30 & 84,3033 & 1,17518 \\
FDR_SebelumBUS & 12 & 77,02 & 82,01 & 79,5000 & 1,52420 \\
\hline CAR_SelamaBUS & 12 & 20,36 & 24,31 & 21,1400 & 1,11881 \\
NPF_SelamaBUS & 12 & 3,13 & 3,43 & 3,2775 & 0,09612 \\
ROA_SelamaBUS & 12 & 1,35 & 2,15 & 1,5325 & 0,26081 \\
BOPO_SelamaBUS & 12 & 82,98 & 86,25 & 85,3508 & 1,18833 \\
FDR_SelamaBUS & 12 & 76,36 & 81,03 & 78,2717 & 1,62461 \\
\hline NPF_SebelumUUS & 12 & 2,57 & 3,09 & 2,8633 & 0,17992 \\
ROA_SebelumUUS & 12 & 1,76 & 2,44 & 1,9675 & 0,21367 \\
BOPO_SebelumUUS & 12 & 75,03 & 80,39 & 78,3775 & 1,75383 \\
FDR_SebelumUUS & 12 & 96,50 & 103,30 & 100,9450 & 1,83241 \\
\hline NPF_SelamaUUS & 12 & 3,01 & 3,42 & 3,1692 & 0,13931 \\
ROA_SelamaUUS & 12 & 1,81 & 2,35 & 2,0467 & 0,16664 \\
BOPO_SelamaUUS & 12 & 71,99 & 78,96 & 76,1017 & 1,98710 \\
FDR_SelamaUUS & 12 & 91,95 & 107,20 & 99,9300 & 5,46234 \\
\hline
\end{tabular}

Berdasarkan pengolahan data masing-masing rasio keuangan yang dikelompokkan menjadi dua, yaitu rata-rata tahun 2019 untuk rasio sebelum pandemi Covid-19 dan periode 2020 untuk rasio selama pandemi Covid-19, dari data tersebut dihasilkan analisis statistik deskriptif sebagai berikut.

a. Pada rasio CAR BUS sebelum dan selama pandemi Covid-19, terdapat dua belas data yang digunakan sebagai sampel penelitian $(\mathrm{N}=12)$ dengan hasil mean masing-masing 20,1233 dan 21,1400. Hal ini menandakan secara rata-rata BUS mengalami peningkatan kecukupan modal untuk menampung risiko kerugian yang dialami dengan adanya peningkatan rasio CAR sebesar 0,102 (1,02\%) dibandingkan sebelum terjadi pandemi. Standar deviasi $=0,41$ dan 1,11 masih mendekati 0 yang menandakan sebaran data tidak terlalu beragam sehingga mean dapat digunakan sebagai parameter untuk mewakili data dalam penelitian. 
Asmirawati, Mia Kurniati | Analisis Perbandingan Kinerja Keuangan BUS dan UUS Antara Sebelum dan Selama Pandemi Covid-19

b. Pada rasio NPF BUS, mean masing-masing 3,4183 dan 3,2775 untuk sebelum dan selama pandemi Covid-19. Hal ini menandakan secara rata-rata BUS mengalami penurunan risiko pembiayaan bermasalah setelah pandemi dengan adanya penurunan rasio NPF selama pandemi sebesar 0,141 $(1,41 \%)$ dibandingkan sebelum pandemi. Sementara untuk NPF UUS, mean masing-masing 2,8633 dan 3,1692 untuk sebelum dan selama pandemi Covid-19. Hal ini menandakan secara rata-rata UUS mengalami peningkatan risiko pembiayaan bermasalah setelah pandemi dengan adanya peningkatan rasio NPF selama pandemi sebesar 0,306 (3,06\%) dibandingkan sebelum pandemi.

c. Pada rasio ROA BUS, mean masing-masing 1,6542 dan 1,5325 untuk sebelum dan selama pandemi Covid-19. Hal ini menandakan secara rata-rata BUS mengalami penurunan rasio ROA sebesar 0,122 (1,22\%) dibandingkan sebelum terjadi pandemi. Hal ini menandakan adanya rentabilitas pada BUS setelah pandemi. Sementara untuk ROA UUS, mean masing-masing 1,9675 dan 2,0467 untuk sebelum dan selama pandemi Covid-19. Rata-rata rasio ROA mengalami penurunan $0,122(1,22 \%)$ dibandingkan sebelum terjadi pandemi menandakan adanya rentabilitas pada UUS setelah pandemi.

d. Pada rasio BOPO BUS, mean masing-masing 84,3033 dan 85,3508 untuk sebelum dan selama pandemi Covid-19. Peningkatan rasio BOPO sebesar $0,105 \quad(1,05 \%)$ menunjukkan rata-rata BUS mengalami penurunan efisiensi kinerja secara operasional selama pandemi. Sementara untuk BOPO UUS, mean masing-masing 78,3775 dan 76,1017 untuk sebelum dan selama pandemi Covid-19. Penurunan rasio BOPO sebesar 0,228 (2,28\%) menunjukkan rata-rata UUS mengalami peningkatan efisiensi kinerja secara operasional selama pandemi.

e. Rasio FDR BUS, mean masing-masing 79,5000 dan 78,2717 untuk sebelum dan selama pandemi Covid-19. Adanya penurunan FDR sebesar 0,123 (1,23\%) menandakan adanya penurunan pemberian pembiayaan pada rata-rata BUS selama pandemi. Sementara untuk FDR UUS, mean masing-masing 100,9450 dan 99,9300 untuk sebelum dan selama pandemi Covid-19. Adanya penurunan FDR sebesar 0,102 $(1,02 \%)$ menandakan adanya penurunan pemberian pembiayaan pada rata-rata UUS selama pandemi.

\section{Uji Hipotesis}

Hasil Uji Wilcoxon signed-rank test Bank Usaha Syariah dijelaskan dalam Tabel 9.

Tabel 9. Hasil Uji Wilcoxon Signed-Rank Test Bank Usaha Syariah

\begin{tabular}{lccccc}
\hline & CAR & NPF & ROA & BOPO & FDR \\
\hline Z & $-2,824$ & $-3,061$ & $-1,414$ & $-1,883$ & $-2,432$ \\
Asymp. Sig. & 0,005 & 0,002 & 0,157 & 0,060 & 0,015 \\
(2-tailed) & & &
\end{tabular}

Sumber: Data diolah SPSS 2021

Tabel 9 menunjukkan ada tidaknya perbedaan antara variabel sebelum dan selama pandemi Covid-19. Berdasarkan output tersebut dapat disimpulkan bahwa.

1. Terdapat perbedaan rasio CAR antara sebelum pandemi Covid-19 dan selama pandemi Covid-19. Hal tersebut ditunjukkan dengan nilai asymp. Sig (2-tailed) yang lebih kecil dari 0,05.

2. Terdapat perbedaan rasio NPF antara sebelum pandemi Covid-19 dan selama pandemi Covid-19. Hal tersebut ditunjukkan dengan nilai asymp. Sig (2-tailed) yang lebih kecil dari 0,05.

3. Tidak terdapat perbedaan rasio ROA antara sebelum pandemi Covid-19 dan selama pandemi Covid-19. Hal tersebut ditunjukkan dengan nilai asymp. Sig (2-tailed) yang lebih besar dari 0,05.

4. Tidak terdapat perbedaan rasio BOPO antara sebelum pandemi Covid-19 dan selama pandemi Covid-19. Hal tersebut ditunjukkan dengan nilai asymp. Sig (2-tailed) yang lebih besar dari 0,05. 
Asmirawati, Mia Kurniati | Analisis Perbandingan Kinerja Keuangan BUS dan UUS Antara Sebelum dan Selama Pandemi Covid-19

5. Terdapat perbedaan rasio FDR antara sebelum pandemi Covid-19 dan selama pandemi Covid-19. Hal tersebut ditunjukkan dengan nilai asymp. Sig (2-tailed) yang lebih kecil dari 0,05.

Tabel 10. Hasil Uji Wilcoxon Signed-Rank Test Unit Usaha Syariah

\begin{tabular}{lcccc}
\hline & NPF & ROA & BOPO & FDR \\
\hline Z & $-3,061^{\mathrm{b}}$ & $-0,942^{\mathrm{b}}$ & $-2,824^{\mathrm{c}}$ & $-0,549^{\mathrm{c}}$ \\
Asymp. Sig. (2-tailed) & 0,002 & 0,346 & 0,005 & 0,583 \\
\hline
\end{tabular}

Sumber: Data diolah SPSS 2021

Tabel 10 menunjukkan ada tidaknya perbedaan antara variabel sebelum dan selama pandemi Covid-19. Berdasarkan Tabel 10 dapat disimpulkan bahwa:

1. Terdapat perbedaan rasio NPF antara sebelum pandemi Covid-19 dan selama pandemi Covid-19. Hal tersebut ditunjukkan dengan nilai asymp. Sig (2-tailed) yang lebih kecil dari 0,05.

2. Tidak terdapat perbedaan rasio ROA antara sebelum pandemi Covid-19 dan selama pandemi Covid-19. Hal tersebut ditunjukkan dengan nilai asymp. Sig (2-tailed) yang lebih besar dari 0,05.

3. Terdapat perbedaan rasio BOPO antara sebelum pandemi Covid-19 dan selama pandemi Covid-19. Hal tersebut ditunjukkan dengan nilai asymp. Sig (2-tailed) yang lebih kecil dari 0,05.

4. Tidak terdapat perbedaan rasio FDR antara sebelum pandemi Covid-19 dan selama pandemi Covid-19. Hal tersebut ditunjukkan dengan nilai asymp. Sig (2-tailed) yang lebih besar dari 0,05.

\section{Pembahasan}

$C A R$

Rasio CAR digunakan untuk mengukur kecukupan modal yang dimiliki bank untuk menunjang aktiva yang mengandung atau menghasilkan risiko. Semakin tinggi CAR maka semakin kuat kemampuan bank tersebut untuk menanggung risiko dan bank mampu membiayai operasional bank. Nilai rata-rata rasio CAR sebelum dan selama pandemi masing-masing yaitu 20\% dan 21\%. Nilai ini tergolong sangat baik karena rasionya lebih besar dari 12\%. Hasil uji Wilcoxon signed-rank test menunjukkan bahwa terdapat perbedaan antara rasio CAR sebelum pandemi dan selama pandemi, maka dapat disimpulkan bahwa H1 terdukung. Selain itu, rasio CAR selama pandemi juga mengalami peningkatan. Hal ini berarti rasio CAR selama pandemi lebih baik dibandingkan sebelum pandemi. Hal ini menandakan bahwa BUS mengalami peningkatan kecukupan modal untuk menampung risiko kerugian yang dialami.

$N P F$

Rasio NPF merupakan rasio pembiayaan bermasalah dengan total pembiayaan. Pembiayaan bermasalah adalah pembiayaan dengan kualitas kurang lancar, diragukan dan macet. Semakin kecil rasio NPF maka semakin baik, artinya semakin sedikit pembiayaan bermasalah dibandingkan dengan total pembiayaan. Berdasarkan hasil uji Wilcoxon signed-rank test pada rasio NPF BUS dan UUS, dapat disimpulkan bahwa H2 dan H3 terdukung. Hal ini berarti terdapat perbedaan yang signifikan antara rasio NPF sebelum pandemi dan selama pandemi. Rasio NPF pada BUS mengalami penurunan yaitu dari 3,41\% sebelum pandemi menjadi 3,27\% selama pandemi, sementara untuk UUS terjadi sebaliknya. Berdasarkan kodifikasi Peraturan Bank Indonesia mengenai tingkat kesehatan bank, rasio NPF pada BUS dan UUS masih dalam predikat sangat baik karena masih berada di bawah $7 \%$.

$R O A$

Rasio ROA memberikan informasi tentang seberapa efisien sebuah bank sedang berjalan karena menunjukkan berapa banyak keuntungan yang dihasilkan (Mishkin, 2016). Semakin besar ROA suatu bank, semakin besar pula tingkat keuntungan yang dicapai bank tersebut dan semakin baik posisi bank tersebut dari segi penggunaan aset. 
Asmirawati, Mia Kurniati | Analisis Perbandingan Kinerja Keuangan BUS dan UUS Antara Sebelum dan Selama Pandemi Covid-19

Berdasarkan hasil uji Wilcoxon signed-rank test pada rasio ROA BUS dan UUS, dapat disimpulkan bahwa $\mathrm{H} 4$ dan $\mathrm{H} 5$ tidak terdukung, artinya tidak terdapat perbedaan yang signifikan antara rasio ROA sebelum pandemi dan selama pandemi. Rasio ROA pada BUS mengalami penurunan yaitu dari $1,65 \%$ sebelum pandemi menjadi $1,53 \%$ selama pandemi, sedangkan rasio ROA pada UUS mengalami peningkatan yaitu dari 1,96\% sebelum pandemi menjadi 2,04\% selama pandemi. Hal ini berarti tingkat keuntungan pada BUS mengalami penurunan yang disebabkan oleh pandemi, sedangkan UUS mengami peningkatan keuntungan yang dihitung berdasarkan rasio ROA. Berdasarkan kodifikasi Peraturan Bank Indonesia mengenai tingkat kesehatan bank, rasio ROA pada BUS dan UUS masih dalam predikat sangat baik.

\section{$B O P O$}

BOPO merupakan rasio efisiensi yang digunakan untuk mengukur kemampuan manajemen bank dalam mengendalikan biaya operasional terhadap pendapatan operasional. Semakin kecil rasio ini berarti semakin efisien biaya operasional sehingga kemungkinan suatu bank dalam kondisi bermasalah semakin kecil. Berdasarkan hasil uji Wilcoxon signed-rank test pada rasio BOPO BUS disimpulkan bahwa H6 tidak terdukung, artinya tidak terdapat perbedaan yang signifikan antara rasio BOPO sebelum pandemi dan selama pandemi. Rasio BOPO BUS sebelum pandemi yaitu sebesar 84,3\% sedangkan selama pandemi yaitu 85,35\%, artinya BUS mengalami penurunan dalam mengendalikan biaya operasional selama pandemi. Sementara berdasarkan hasil uji Wilcoxon signed-rank test pada rasio BOPO UUS disimpulkan bahwa H7 terdukung, artinya terdapat perbedaan yang signifikan antara rasio BOPO sebelum pandemi dan selama pandemi. Rasio BOPO sebelum pandemi yaitu sebesar $78,37 \%$ sedangkan selama pandemi yaitu 76,1\%, artinya manajemen UUS mampu melakukan efisiensi selama pandemi. Rasio BOPO ini menunjukkan bahwa baik BUS maupun UUS masih dalam predikat baik jika dilihat dari penilaian Bank Indonesia terkait tingkat kesehatan bank.

FDR

Rasio FDR menunjukkan tingkat kemampuan bank dalam menyalurkan dananya yang berasal dari masyarakat (berupa: giro, tabungan, deposito berjangka, sertifikat deposito berjangka, dan kewajiban segera lainnya) dalam bentuk pembiayaan (Riyadi, 2015). Semakin tinggi nilai rasio FDR menunjukkan semakin rendahnya likuiditas bank yang bersangkutan sehingga kemungkinan bank tersebut dalam kondisi bermasalah akan semakin besar. Namun semakin rendah rasio FDR menunjukkan kurangnya efektivitas bank dalam menyalurkan pembiayaan sehingga hilangnya kesempatan bank untuk memperoleh laba. Berdasarkan hasil uji Wilcoxon signed-rank test pada rasio FDR BUS dapat disimpulkan bahwa H8 terdukung, artinya terdapat perbedaan yang signifikan antara rasio FDR BUS sebelum pandemi dan selama pandemi. Rasio FDR BUS sebelum pandemi yaitu sebesar 79,5\% sedangkan selama pandemi yaitu $78,27 \%$. Berdasarkan kriteria penilaian tingkat kesehatan bank yang dikeluarkan oleh Bank Indonesia, rasio FDR untuk BUS berada dalam predikat atau kondisi baik.

Di sisi lain, berdasarkan hasil uji Wilcoxon signed-rank test pada rasio FDR UUS dapat disimpulkan bahwa H9 tidak terdukung, artinya tidak terdapat perbedaan yang signifikan antara rasio FDR UUS sebelum pandemi dan selama pandemi. Rasio FDR UUS sebelum pandemi yaitu sebesar 100,94\% sedangkan selama pandemi yaitu 99,93\%. Berdasarkan kriteria penilaian tingkat kesehatan bank yang dikeluarkan oleh Bank Indonesia, rasio FDR UUS sebelum pandemi berada dalam kondisi tidak baik dan mengalami peningkatan selama pandemi, predikatnya berubah dari tidak baik menjadi cukup.

\section{SIMPULAN, KETERBATASAN, DAN SARAN}

Terdapat perbedaan rata-rata rasio CAR pada BUS, NPF pada BUS dan UUS, BOPO pada UUS, dan FDR pada BUS sebelum dan selama pandemi Covid-19. Artinya, pandemi Covid-19 memberikan dampak pada rasio tersebut. Sementara untuk rata-rata rasio ROA 
Asmirawati, Mia Kurniati | Analisis Perbandingan Kinerja Keuangan BUS dan UUS Antara Sebelum dan Selama Pandemi Covid-19

pada BUS dan UUS, BOPO pada BUS, dan FDR pada UUS sebelum dan selama pandemi tidak terdapat perbedaan, artinya pandemi Covid-19 tidak memberikan dampak pada rasio tersebut. Akan tetapi jika dilihat dari matriks Bank Indonesia mengenai tingkat kesehatan bank, BUS dan UUS masih dalam kondisi yang sehat dan masih mampu bertahan di tengah pandemi Covid-19. Adapun keterbatasan dalam penelitian ini, penulis tidak menggunakan rasio CAMEL secara keseluruhan, karena keterbatasan dalam pengumpulan data. Penelitian selanjutnya diharapkan mampu menggunakan rasio CAMEL secara keseluruhan agar hasilnya dapat menunjukkan tingkat kesehatan keuangan bank dari seluruh aspek.

\section{DAFTAR PUSTAKA}

Al Faqir, A. (2021). Kinerja Sektor Perbankan selama 2020 Terkontraksi Akibat Pandemi Covid-19. https://www.liputan6.com/bisnis/read/4458547/kinerja-sektorperbankan-selama-2020-terkontraksi-akibat-pandemi-covid-19

Arimi, M., \& Mahfud, M. (2012). Analisis Faktor-Faktor yang Mempengaruhi Profitabilitas Perbankan (Studi Pada Bank Umum yang Listed di Bursa Efek Indonesia Tahun 2007-2010). Diponegoro Journal of Management, 1(4), 80-91. https://ejournal3.undip.ac.id/index.php/djom/article/view/773

Budisantoso, T., \& Nuritomo. (2014). Bank dan Lembaga Keuangan Lain. Salemba Empat.

CNN Indonesia. (2021). OJK Prediksi Risiko Kredit Macet Masih Menanjak. CNN Indonesia. $\quad$ https://www.cnnindonesia.com/ekonomi/20210226150445-78611349/ojk-prediksi-risiko-kredit-macet-masih-menanjak

Fitriani, P. D. (2020). Analisis Komparatif Kinerja Keuangan Bank Umum Syariah Pada Masa Pandemi Covid-19. Jurnal Ilmu Akuntansi Dan Bisnis Syariah, 2(2), 113-124. https://doi.org/10.15575/aksy.v2i2.9804

Fusva, A., Dean, D., Suhartanto, D., Syarief, M. E., Arifin, A. Z., Suhaeni, T., \& Rafdinal, W. (2020). Loyalty formation and its impact on financial performance of Islamic banksevidence from Indonesia. Journal of Islamic Marketing. https://doi.org/10.1108/JIMA-12-2019-0258

Golovkova, A., Eklof, J., Malova, A., \& Podkorytova, O. (2019). Customer satisfaction index and financial performance: a European cross country study. International Journal of Bank Marketing, 37(2), 479-491. https://doi.org/10.1108/IJBM-10-2017-0210

Ichsan, R. N., Suparmin, S., Yusuf, M., Ismal, R., \& Sitompul, S. (2021). Determinant of Sharia Bank's Financial Performance during the Covid-19 Pandemic. Budapest International Research and Critics Institute (BIRCI-Journal): Humanities and Social Sciences, 4(1), 298-309. https://doi.org/10.33258/birci.v4i1.1594

Joel, Siegel G., \& Shim, J. (1994). Kamus Istilah Akuntansi. PT Elex Media Komputindo.

Ledhem, M. A., \& Mekidiche, M. (2020). Economic growth and financial performance of Islamic banks: a CAMELS approach. Islamic Economics Studies, 28(1), 47-62. https://doi.org/10.1108/IES-05-2020-0016

Mishkin, F. (2016). The Economics of Money, Banking, and Financial Markets. Columbia University.

Munir, A. S. (2017). Analisis Faktor-Faktor yang Mempengaruhi Kinerja Keuangan Perbankan di Indonesia. Ummul Qura: Jurnal Ilmiah Institut Pesantren Sunan Drajat (INSUD), $9(1)$, $56-68$. http://ejournal.kopertais4.or.id/pantura/index.php/qura/article/view/3043/2201

Peraturan Bank Indonesia Nomor 9/13/PBI/2007 tentang Kewajiban Penyediaan Modal Minimum Bank Umum dengan Memperhatikan Risiko Pasar.

Purwoko, D., \& Sudiyatno, B. (2013). Faktor-Faktor yang Mempengaruhi Kinerja Bank (Studi Empirik Pada Industri Perbankan di Bursa Efek Indonesia). Jurnal Bisnis Dan

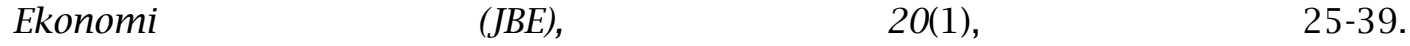
https://www.unisbank.ac.id/ojs/index.php/fe3/article/view/2344/790

Putri, A. M., \& Iradianty, A. (2020). Analisis Perbandingan Kinerja Keuangan Perbankan Syariah Dengan Perbankan Konvensional 2015-2019. Jurnal Mitra Manajemen, 4(8), 1103-1117. https://doi.org/10.52160/ejmm.v4i8.438 
Asmirawati, Mia Kurniati | Analisis Perbandingan Kinerja Keuangan BUS dan UUS Antara

Sebelum dan Selama Pandemi Covid-19

Putri, E., \& Dharma, A. B. (2016). Analisis Perbedaan Kinerja Keuangan Antara Bank Konvensional Dengan Bank Syariah. Riset Akuntansi Dan Keuangan Indonesia, 1(2), 98-107. https://doi.org/10.23917/reaksi.v1i2.2734

Rashid, A., Yousaf, S., \& Khaleequzzaman, M. (2017). Does Islamic banking really strengthen financial stability? Empirical evidence from Pakistan. International Journal of Islamic and Middle Eastern Finance and Management, 10(2), 130-148. https://doi.org/10.1108/IMEFM-11-2015-0137

Riyadi, S. (2015). Banking Assets And Liability Management. Lembaga Penerbit Fakultas Ekonomi Universitas Indonesia.

Setyawati, I., Suroso, S., Suryanto, T., \& Nurjannah, D. S. (2017). Does financial performance of Islamic banking is better? Panel data estimation. European Research Studies Journal, 20(2A), 592-606. https://doi.org/10.35808/ersj/661

Sudarsono, H. (2012). Bank dan Lembaga Keuangan Syariah: Deskripsi dan Ilustrasi. Eksoria.

Surya, Y. A., \& Asiyah, B. N. (2020). Analisis Perbandingan Kinerja Keuangan Bank BNI Syariah dan Bank Syariah Mandiri di Masa Pandemi Covid-19. Jurnal Ekonomi Dan Perbankan Syariah, 7(2), 170-187. https://doi.org/10.19105/iqtishadia.v7i2.3672

Thayib, B., Murni, S., \& Maramis, J. B. (2017). Analisis Perbandingan Kinerja Keuangan Bank Syariah Dan Bank Konvensional. Jurnal Riset Ekonomi, Manajemen, Bisnis dan Akuntansi (EMBA), 5(2), 1759-1769. https://doi.org/10.35794/emba.v5i2.16392

Undang-Undang Nomor 21 Tahun 2008 tentang Perbankan Syariah. 